\title{
PUTTING A BUSINESS MINDSET INTO STEM EDUCATION AND CAREER PLANNING
}

\author{
Darryl Brinkmann, Missouri University of Science \& Technology, brinkmannd@mst.edu \\ J. Edward Harvey, Missouri University of Science \& Technology, harveyej@mst.edu \\ Cui Zou, Missouri University of Science \& Technology,cz87c@mst.edu \\ Rebecca J. Crosthwait, Missouri University of Science \& Technology, crosthwaitr@mst.edu \\ Cassandra C. Elrod, Missouri University of Science \& Technology, cassa@mst.edu \\ Barry B Flachsbart, Missouri University of Science \& Technology, barryf@mst.edu
}

\begin{abstract}
Employment results for STEM (Science, Technology, Engineering, and Mathematics) graduates continue to encourage exposure to business aspects as well as technical expertise. STEM students are increasingly recognizing the value of filling their electives with business-related classes or in complementing their STEM degree with a Business Minor. This paper illustrates some techniques that aid students in thinking about where they expect their career to be in 10 to 20 years and identifies steps that can be taken during initial degree planning and career planning to meet those expectations. Some of these techniques involve student participation in case studies that put them in a management role and cause students to realize two things: 1) the decisions they need to make are often gut-wrenching because they affect employees and their families; and 2) there may be more than one right answer, depending on the circumstances.
\end{abstract}

Keywords: STEM Education, Employment Trends, Curriculum Development, Career Planning, Business

\section{INTRODUCTION}

Many efforts have been made to generate greater student interest and engagement in STEM careers. Recently, the National Science Foundation, federal and state departments of education, as well as the Department of Defense addressed the ongoing issues of bridging the gap between classroom efforts in STEM subjects and student engagement in STEM career paths (Schmidt, Hardinge, \& Rokutani, 2012). While classroom efforts have gained support and proved to be effective (Feller, 2009, 2010; Morganson, Jones, \& Major, 2010), it is too early to say that we have overcame "our generation's Sputnik moment (Obama, 2011)." The conclusions from previous studies (Elrod, Stanley, Flachsbart, Hilgers, \& Cudney, 2015; Flachsbart, Elrod, \& Kehr, 2010; Flachsbart \& Elrod, 2011) reinforce the need for STEM students to be exposed to business aspects as well as to technical topics and to consider both aspects when dealing with career planning. Today, many STEM students recognize this need and take elective classes that are business-related or even complement their STEM degree with a Business Minor. Students need to be encouraged to think about where they expect their career to be in 10 to 20 years. There are a number of steps and techniques that can be taken during initial degree planning and career planning to help them get to those goals. Some of these techniques involve student participation in case studies that put them in a management role and cause students to realize two things: 1) the decisions they need to make are often gut-wrenching, because they affect employees and their families; and 2) there may be more than one right answer, depending on the circumstances. However, students also learn to recognize that many business decisions demand the same analytical thinking they use in their STEM classes.

\section{LITERATURE REVIEW}

A number of articles have explored various aspects of broadening technology curriculum by adding topics or courses. The employability benefits of introducing marketing topics into technology courses was discussed by Elrod, et al. (2009). A follow-up, viewing the process as a graduate to industry supply chain, involved collection of 
post-graduate perceptions (Flachsbart \& Elrod, 2011). Flachsbart, et al. (2010) also explored the impacts of inserting business concepts into an information technology course, where the final message was that "getting the technical details wrong can mess up business decisions and that making inappropriate business decisions can make the technology irrelevant." These papers, and others, followed McBane's (2003) earlier paper which had noted that "Employees with an understanding of both technology and business processes are becoming valuable commodities. A new position is being created in many businesses today: the 'IT business analyst,' who works as a liaison between the IT department and the non-IT employees who have a business problem to solve." McBane (2003) was dealing with putting technology into business and marketing courses, which is the other side of the picture.

Elrod, et al. (2010) dealt with using case studies in project management to teach students the value of communication skills and the necessity of dealing with different people at different levels, while working with local communities to help them select projects.

More recently, Hilgers, et al. (2015) discussed the creation of course content within a blended computing-business department that prepared students for jobs in several aspects of "big data" work within companies. Their conclusion was that with the addition of a few courses, graduates could operate as data analysts or data explorers and contribute to fulfilling the needs for big data expertise in industry. Elrod, et al. (2015) also explored the views of students and of industry hiring professionals on perceptions of professional behavior, looking at computing, engineering, and business students.

Career planning for students and the history of a career development strategy at a major Australian University was discussed by Miller and Liciardi (2003), in which they found that "fundamental to the development of a fulfilling career which is suited to one's life goals is the formulation of strategic career plans during undergraduate study." Students reported that the benefits of taking control and managing their careers far exceeded their expectations of the subject (Miller \& Liciardi, 2003). This planning was provided for a wide range of students, not just for STEM students.

Specific needs for STEM skills were described by Prinsley and Baranyai (2015), and they reported on employer perceptions of STEM qualified people, including the skills and attributes that they bring to the marketplace. Several things stood out from this report as it impacts career planning. First, employers overwhelmingly identified "communication" as an important skill that needed to be included in the survey. Second, employers ranked "lack of business understanding" highest when reporting on applications from candidates with unsatisfactory skills.

\section{THEORETICAL BACKGROUND AND PROPOSED SOLUTIONS}

\section{Career Planning}

It is often assumed that many students seeking a degree in a STEM discipline choose that field because of their interest in the profession. Many students believe the pursuit of a career in science, technology, engineering, or mathematics will lead to a high level of satisfaction in life. Other students pursuing a technical education often discover they are looking for the added challenge of leading a work team for an existing business, or striking out as an entrepreneur. Kinicki (2015) indicates that three of the most important skills exceptional managers need include technical, conceptual, and human skills. A STEM education would appear to contribute to the development of strong technical and conceptual skills, providing some of the skills a manager needs.

At the undergraduate level, the primary focus should be on developing an awareness of management and technical career tracks, not the selection of a career track at this point in a person's life. However, experience has indicated that a number of students will already tell you they are seeking a senior leadership role in their career.

A "Career Planning Exercise" that can be used to help motivate students might 1) ask students to demonstrate how they are taking advantage of the career-oriented opportunities and assistance offered to students through the university and campus-related organizations; 2) ask questions related to the reason for their choice of a major; and 3) 
ask about expectations for positions in 10 to 20 years. Recognition that most careers will involve a lifetime of learning is the likely outcome of these questions.

In addition to encouraging students to begin thinking about a future career before they graduate, a Career Planning Exercise also introduces students to the development of a career plan and the efforts that many companies undertake to help capture these plans.

\section{Sphere of Influence}

Employees and students interested in developing a career plan soon recognize they are surrounded by a "Sphere of Influence." This sphere is made up of the people (co-workers, supervisors, customers and fellow students) they deal with. Franklin Covey (2013) describes a "Circle of Influence" that helps illustrate this concept, shown in Figure 1.

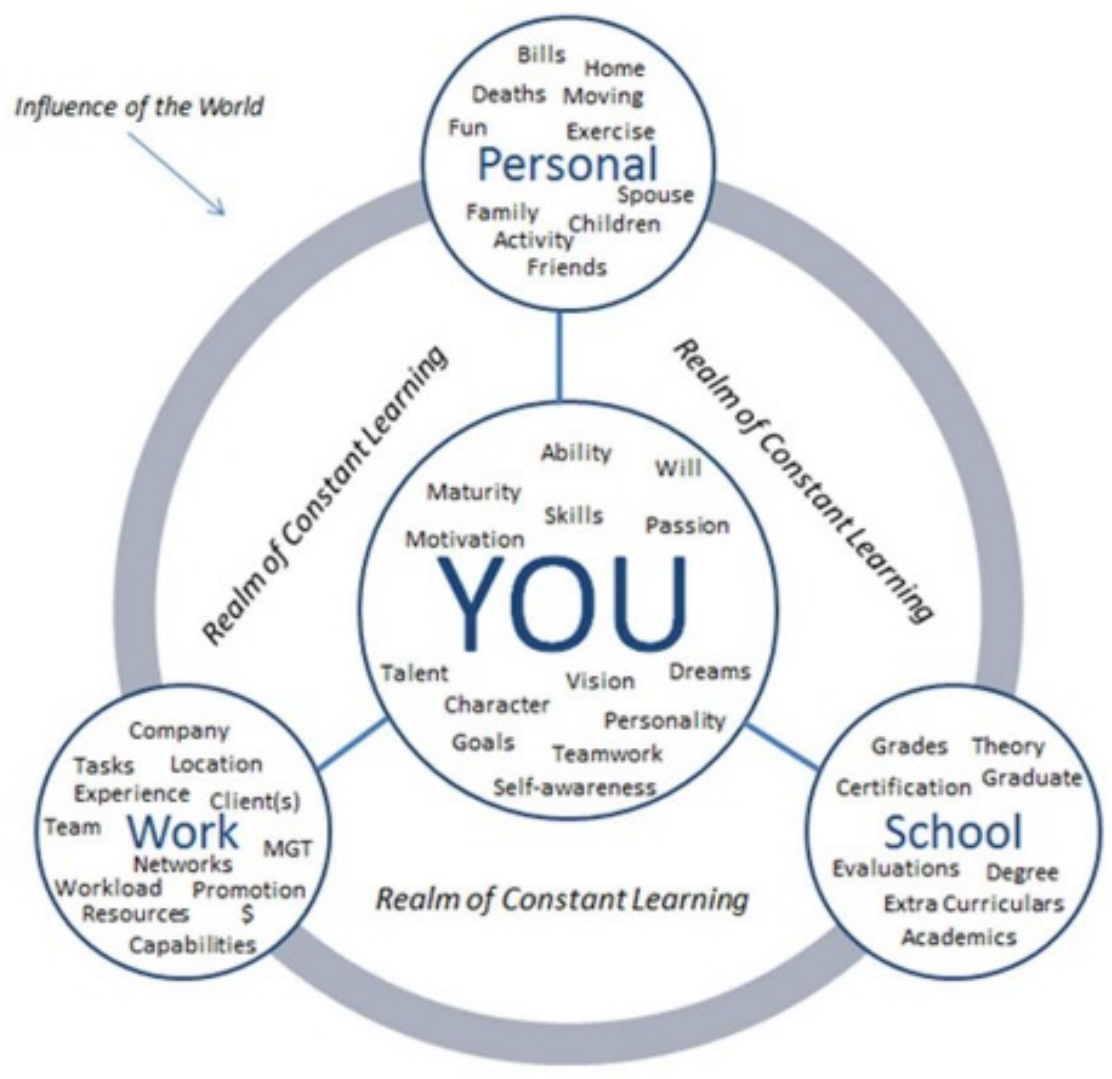

Figure 1. Circle of Influence

One of the most important aspects of leadership is influence. An individual's sphere of influence usually develops over time as the individual contributes significantly to the organization's goals. In a career sense, building a sphere of influence helps meet career goals. Success in reaching career goals often starts with a strong mentor. This mentor not only helps make a person aware of different career opportunities, but the mentor can help recommend the proven career steps that others have used to achieve their goals. Since most decisions to move or promote a person are usually made by teams of managers, especially as an individual moves beyond an entry level position, tools like the "Sphere of Influence" are useful in capturing a person's contributions to the organization. These contributions provide evidence of accomplishment that mentors and supervisors can use to acquaint others with the individual being considered for a position.

Figure 2 illustrates a "Sphere of Influence" document. In the first column, the individual lists the various projects they wish to highlight that they participated in. The next column lists the actual contribution the candidate made to 
the project. In other words, what did you do that is noteworthy? Most employees will eventually be part of a major project, but it is often hard to pinpoint why the particular employee's participation was critical to the project's success. This document attempts that specification.

Name

Sphere of Influence

$\begin{array}{lllll} & \text { Dollar } & & & \\ \text { Project } & \text { Contribution } & \text { Value } & \text { Timeframe } & \text { Reference \#1 }\end{array}$

Figure 2. "Sphere of Influence" Document

In the third column, the individual lists the dollar value of the project. This can reflect the value of any cost savings or cost avoidance realized because of the project. If an actual dollar amount cannot be entered, an estimate of the individual's contribution may be the only thing available. The next column normally contains the project's timeframe. This can serve as a reminder of "what you have done for us lately." In the last two or three columns, the individual is asked to list the contact information for two or three managers who can vouch for the success of the project, and most importantly, speak to the individual contribution made to the project. Users sometimes ask, why list more than one reference familiar with the project? The reality is that people retire or change jobs, and they may not be available to respond to an inquiry. Obviously, the goal here is to list senior managers whose names will carry more weight with future decision makers evaluating the individual's future potential.

Students exposed to this as a possible tool for evaluating themselves should gain an increased understanding of the value of broad educational that go beyond the technical details in their STEM courses.

\section{Employee Datasheet}

According to vocational psychology, work-related choices could be predicted by reviewing the match between personal interests and work environments (van Tuijl \& van der Molen, 2016). Among the many models in this field, Holland's RIASEC (Realistic, Investigative, Artistic, Social, Entrepreneurial and Conventional) model is the most analyzled (Spokane, Meir, \& Catalano, 2000): "A dozen literary reviews and two meta-analyses of congruence research, operationally defined using John Holland's (1959) theory, continue to reveal a mixture of significant and non-significant relations between congruence and a variety of work-related behaviors" (p. 137). Both an individual's personality type and vocational aspirations can fall in one of those six categories: realistic, investigative, artistic, social, entrepreneurial, or conventional. Theoretically, based on selective orientations (e.g. social environment versus the physical environment and data versus ideas), Holland's RIASEC model is capable of explaining how the expression of personal interests is motivated and developed among cognitive and social activities (van Tuijl \& van der Molen, 2016).

Based on Holland's theory, it is also helpful to introduce students to some of the other tools used by companies to help manage talent. An effective "Talent Management System" (TMS), found in many companies, combines elements of career planning and development into a common document, often referred to as an employee datasheet.

The typical employee datasheet includes a mix of information from positions held, education and development records, past performance, employee relocation interests, and future positions to be considered for. Often this is the section where the employee can also identify different parts of the world where they have lived and any foreign language capabilities they possess. An effective TMS can also serve to facilitate meaningful career planning 
discussions between managers and employees. The confirmation of accurate employee records in the datasheet normally rests with the employee.

The typical TMS process starts with a summary of employee information easily captured by modern HR Information Systems, even in the global environment many companies operate in today. The employee then reviews these work records, updating outside training and education not captured by company training records. The last two steps requiring employee input are an employee's relocation preferences (critical in a world with two-income families) and their preferences for future positions. When challenged, many employees determine they are quite satisfied with their current position and location, so any career planning discussions often focus on additional training needed to be more effective in their current role.

For employees hoping to see their career advance to positions of more responsibility, a TMS provides an opportunity for the employee to make those interests known. The next step in the process is a meeting with their supervisor to review those interests. Ideally, the discussions that follow validate the company's support for those career goals and lead to the creation of a "Career Development Plan" (CDP). If not, the employee may have to modify their career goals or update their resume. It is important that students begin to recognize the necessity for life-long learning in their careers, and to understand the advantage of mobility in seizing new opportunities that may mean relocation.

\section{Example}

An example of how employee information can be used to manage talent within a global enterprise can be found at LG Electronics (LG, 2016). As part of their corporate philosophy to "Respect Human Dignity," they provide employees an outline of their "Talent Management" process (9). LG (2016) states, "Employees set their career development paths based on their capabilities and aspirations, and LG Electronics provides training programs accordingly." The career development paths are directed to one of three career tracks: Expert, Function Leader, and Business Leader.

Assuming management and the employee agree on the career development path, it becomes a formal CDP with goals and reviews to ensure the CDP remains on target. For high potential employees, the CDP is designed to provide the development opportunities that will prepare employees for a "Business Leader" position in the future. For other employees, the CDP focuses on "Job Assignment Training" to help them excel in their current role.

The talent management processes at companies like LG and others validate the benefit of encouraging students to start thinking about a career track before they leave school. The attached figures contain examples of employee datasheets and career planning tools where employees and supervisors have the chance to document their training, their accomplishments and their future career choices.

\section{The Value of Market Discussions in Classrooms}

According to van Tuijl et al. (2016), study choice and career development can be analyzed through the educational studies perspective, especially for the STEM majors. Curriculum content, design and innovation are one line of research that has been employed in educational studies (van Tuijl \& van der Molen, 2016). Osborne et al. (2003) in their review contend that activities related to real life experiences are needed in science education.

The dynamic nature of future employment opportunities suggests that instructors need to help students understand current economic trends to prepare them to evaluate future trends. For example, one can point to recent trends in the oil industry. A senior level petroleum engineering student saw oil prices over $\$ 100$ a barrel when they started college, and now face the reality of limited employment opportunities in the oil industry with oil trading at $\$ 40$ a barrel.

Developments like those in the oil industry point to the importance of understanding the impact that markets can have on future career opportunities for students. This can be another opportunity for instructors to remind students of the importance of tools like the Sphere of Influence to help managers and prospective employers identify 
candidates for future employment opportunities. Time spent populating a spreadsheet listing work experiences, cost impacts and references may prove to be an important tool to validate a person's qualifications for another career track. Career tracks today may look much different than they did a generation ago.

Human nature often tries to view life as a static environment, which can encourage students to choose a college major based on a limited perception of what they would like to do with the rest of their life. Graduates in the 1960's and 1970's could often assume that their college degree was the entry ticket to a lifetime career with a company that assumed responsibility for managing their career. Today, companies value flexibility and often want to lease assets, even employees, in the form of a contingent workforce.

Finally, Knicki and Mel (2015) point out that "Managing for your own happiness and life goals" is one of the "seven challenges to being an effective manager." Maslow's Hierarchy of Needs Theory (Maslow, 1954) also reminds us that Self-Actualization is at the top of the motivational pyramid. The better prepared that students are for change when they enter the business world will help to ensure their future success and happiness.

\section{Using Case Studies}

Another technique used in the classroom involves student participation in case studies that put them in a management role. At the end of every chapter, many textbooks, like Kinicki (2015), provide real-life examples of typical business decisions for students to evaluate. Students can choose from several options of how a manager might respond in the case study. The use of classroom voting tools allows the vote totals to be displayed, so the results can be analyzed by the entire class.

Examples that have been used (Kinicki \& Fugate, 2015) include:

- A company's response to a whistle blower when it was later proved that the accusations were false. In this case, senior managers were unfairly terminated.

- A high school principal's decision on whether to allow Native American students to wear eagle feathers during their graduation ceremony, even though the school board had indicated that graduates are only allowed to wear a traditional cap and gown.

- Should senior members of management receive a bonus for successfully navigating a company through bankruptcy proceedings? In this case, part of the solution was eliminating excess manufacturing capacity and laying off hundreds of employees, while managers received six-figure bonuses.

In each of these case studies, students realize that managers often have to make unpopular decisions. They also learn to balance their emotions with the facts and to use the same analogical thinking they use in their STEM classes. They normally discover most business decisions do not have one right or wrong answer, and it pays to gather as many facts as possible before making a decision.

This tool provides another benefit, too, because even students that may not be entirely comfortable speaking out in class, normally jump in and share the reasons for their decision. The discussion in the classroom becomes more like a business meeting as students realize that the best opinions in the world have little value if no one hears them.

\section{CONCLUSIONS AND FUTURE RESEARCH DIRECTIONS}

The future for many STEM graduates involves a growing need for business knowledge. There are a number of ways that STEM students can approach planning for such careers. Such planning is best begun during undergraduate studies, when business knowledge can often be acquired concurrently with technical knowledge. Several techniques can help STEM students use their analytical skills for business problems.

Future research might recruit college students with STEM majors and conduct a within-subjects experiment to empirically evaluate the effectiveness of those tools and, if effective, which one is the most effective or which combination works best. 


\section{REFERENCES}

Covey, S. R. (2013). The 7 habits of highly effective teens: Simon and Schuster.

Elrod, C. C., Flachsbart, B. B., \& Kehr, W. R. (2009). Improving student employability by embedding marketing concepts in information science and technology courses. Issues in Information Systems, 10(1), 155-166.

Elrod, C. C., Murray, S., Flachsbart, B. B., Burgher, K. E., \& Foth, D. M. (2010). Utilizing multimedia case studies to teach the professional side of project management. Journal of STEM Education: Innovations and Research, 7.

Elrod, C. C., Stanley, S. M., Flachsbart, B. B., Hilgers, M. G., \& Cudney, E. A. (2015). Assessing professional behavior perceptions between computing, engineering, and business students and hiring employers. Issues in Information Systems, 16(1).

Feller, R. (2009). STEM centric career development: Sputnik II or a thud? Career Planning \& Adult Development Journal, 25, 19-35.

Feller, R. (2010). STEM centric career development: Building bright futures from main street to outer space. NCDA Career Developments, 5-9.

Flachsbart, B., Elrod, C., \& Kehr, W. (2010). Inserting Business Concepts into an Information Systems Course. Journal of Communication and Computer, 7(8), 54-57.

Flachsbart, B. B., \& Elrod, C. C. (2011). Graduate to industry supply chain: Post-graduation perception of the value of embedding marketing concepts in Information Science and Technology courses. Issues in Information Systems, 12(2), 8 .

Hilgers, M. G., Stanley, S. M., Elrod, C. C., \& Flachsbart, B. B. (2015). Big data and business analytics in a blended computing-business department. Issues in Information Systems, 16(1).

Holland, J. L. (1959). A theory of vocational choice. Journal of Counseling Psychology, 6(1), 35-45. doi: $10.1037 / \mathrm{h} 0040767$

Kinicki, A., \& Fugate, M. (2015). Organizational Behavior: A Practical, Problem-Solving Approach.

LG. (2016). Talent management based on the corporate philosophy of "Respect for Human Dignity". Retrieved May 13, 2016, from http://www.lg.com/global/sustainability/employee/talent-management

Maslow, A. H. (1954). Motivation and Personality. New York, NY: Harper.

McBane, D. A. (2003). Getting the horse to drink: Teaching technology to marketing students. Marketing Education Review, 13(2), 1-6.

Miller, S., \& Liciardi, R. (2003). Tertiary student perceptions of the benefits of professional career management education: an exploratory study. Career Development International, 8(6), 309-315.

Morganson, V. J., Jones, M. P., \& Major, D. A. (2010). Understanding women's underrepresentation in science, technology, engineering, and mathematics: The role of social coping. Career Development Quarterly, 59(2), 169-179.

Obama, B. (2011). Remarks by the President in State of the Union Address. Retrieved May, 13, 2016, from https://www.whitehouse.gov/the-press-office/2011/01/25/remarks-president-state-union-address 
Osborne, J., Simon, S., \& Collins, S. (2003). Attitudes towards science: A review of the literature and its implications. International Journal of Science Education, 25(9), 1049-1079. doi: $10.1080 / 0950069032000032199$

Prinsley, R., \& Baranyai, K. (2015). STEM skills in the workforce: what do employers want. Office of the Chief Scientist, Canberra.

Schmidt, C. D., Hardinge, G. B., \& Rokutani, L. J. (2012). Expanding the school counselor repertoire through STEM-focused career development. Career Development Quarterly, 60(1), 25-35. doi: 10.1002/j.21610045.2012.00003.x

Spokane, A. R., Meir, E. I., \& Catalano, M. (2000). Person-Environment Congruence and Holland's Theory: A Review and Reconsideration. Journal of Vocational Behavior, 57(2), 137-187. doi: 10.1006/jvbe.2000.1771

van Tuijl, C., \& van der Molen, J. H. W. (2016). Study choice and career development in STEM fields: an overview and integration of the research. International Journal of Technology and Design Education, 26(2), 159-183. doi: $10.1007 / \mathrm{s} 10798-015-9308-1$ 